\title{
Monopoly Media: Efforts to Increase the Activity of Elementary School Students in Learning Animals Movement Organs
}

\section{Luh Ayu Ratna Sawitri Prabali1*, Adrianus I Wayan Ilia Yuda Sukmana²}

1,2 Universitas Pendidikan Ganesha, Singaraja, Indonesia

\section{A R T I C L E I N F O}

Article history:

Received March 08, 2021

Revised March 11, 2021

Accepted April 30, 2021

Available online May 25, 2021

Kata Kunci:

Gerak Hewan, Media

Monopoli

Keywords:

Animal's Movement

Monopoly Media

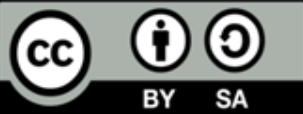

This is an open access article under the CC BY-SA license.

Copyright (C) 2021 by Author. Published by Universitas Pendidikan Ganesha.

\begin{abstract}
A B S T RA K
Rendahnya hasil belajar siswa kelas $V$ disebabkan oleh kurangnya media pembelajaran yang mampu melibatkan partisipasi aktif siswa dalam proses pembelajaran tematik terpadu. Oleh sebab itu, penelitian ini bertujuan untuk menghasilkan media pembelajaran sederhana monopoly pada subtema organ gerak hewan. Penelitian ini adalah penelitian pengembangan dengan berpedoman pada model ADDIE. Data yang dikumpulkan dalam penelitian ini yaitu data kualitatif dan data kuantitatif dengan subjek penelitian yaitu seorang ahli materi, seorang ahli media, seorang ahli desain pembelajaran, serta seorang praktisi pembelajaran. Data dalam penelitian ini dikumpulkan dengan kuisioner dan selanjutnya dianalisis menggunakan analisis deskriptif kualitatif dan analisis deskriptif kuantitatif. Hasil penelitian menunjukkan bahwa media pembelajaran sederhana monopoly yang dikembangkan valid berdasarkan review ahli materi, review ahli media pembelajaran, dan review ahli desain pembelajaran dengan kualifikasi sangat baik. Sedangkan berdasarkan hasil review praktisi untuk mengetahui respon guru terhadap media yang dikembangkan, media monopoly dinyatakan berkualifikasi sangat baik digunakan dalam pembelajaran tematik terpadu subtema organ gerak hewan. Jadi dapat disimpulkan bahwa media pembelajaran sederhana monopoly yang dikembangkan layak digunakan dalam pembelajaran tematik terpadu subtema organ gerak hewan. Implikasi media pembelajaran sederhana monopoly yaitu dapat membantu siswa terlibat aktif dalam pembelajaran yang bermakna dan menyenangkan.
\end{abstract}

A B S T R A C T

\begin{abstract}
The low learning outcomes of fifth-grade students are caused by the lack of thematic learning media. Therefore, this study aimed at developing simple monopoly learning media on the subtheme of animal movement organs. The design of this study was development research based on ADDIE model. The collected data in this study were qualitative and quantitative data. The subjects in this study were a material expert, a media expert, an instructional design expert, and a learning practitioner. The data were collected through questionnaire. Then, the collected data were analyzed using descriptive qualitative and descriptive quantitate method. The results of this study show that the simple monopoly learning media developed is valid based on a review of material experts, reviews of learning media experts, and reviews of learning design experts with very good qualifications. Meanwhile, this learning media has good qualification to be used in thematic learning on the subtheme of animal movement organs. It is based on the result of teacher's response to the developed media. It can be concluded that the monopoly learning media is suitable to in the thematic learning specially for learning animal movement organs. The implication of the result of this study is that it can help students be actively involved in meaningful and fun learning.
\end{abstract}

\section{INTRODUCTION}

Learning is a process designed to create interaction between educators, students, and learning resources in a learning environment. The ideal learning is learning that takes place systematically and is able to provide meaningful activities to students ( $\mathrm{Ng}$, 2015). Ideal learning can improve cognitive activities and attitudes of responsibility that will foster discipline in students (Skuballa et al., 2018). It 
aims to help students wisely in dealing with all phenomena encountered in their lives (Brown \& Flood, 2020; Raggl, 2015). With well-designed and optimal learning, the learning objectives in the form of improving the quality of student competencies will be achieved effectively. Quality learning will be achieved if the teachers have various techniques and good teaching and good teaching facilities and supported by an ideal learning environment (Hui et al., 2021). In achieving the competence of students in accordance with expectations, the use of effective learning strategies is an importance factor that cannot be ignored. Interventions in the form of using effective learning strategies usually targeting motivation and knowledge of students (Lin et al., 2021). The use of learning strategies in elementary school can run effectively if the implementation of the learning pays attention to the main characteristics of student development. The main characteristics of the development of elementary school ages students according to Murdoch is a holistic and integrated mindset, therefore that one aspect of development is related and affects other aspects of development (Ilham, 2015). This development will be integrated with experience, life, and the environment therefore that the learning process in elementary schools must be based on concrete objects and direct experiences of students (Fakhrurrazi, 2018). The achievement of ideal learning through the use of learning strategies cannot be separated from the role of learning media. Learning media is one of the supports for the successful implementation of the learning process. Learning media has a function as a tool for students to gain concrete understanding and knowledge. This understanding will be obtained if students can contribute to the use of media (Nugroho, 2019; Yulianti, 2019). In simple term, a good learning media is a media which can transform the material well, can be used directly by students, and can create a pleasant education atmosphere.

Observation activities that have been carried out show that in the reality, the practice of learning at SD N 4 Peliatan tend a teacher center which relies more on the lectured method to deliver subject matter to students. In general, this type of learning style causes student to be less enthusiastic in participating in learning which causes the class atmosphere to become passive. If left unchecked, this will have a negative impact for student's achievement which is marked by a low understanding of the subject matter presented. In addition, learning resources are only limited to the materials in the Theme Package Book, therefore that curiosity does not arise from within students. Teacher centered learning requires a paradigm shift to students centered learning (student center) will provide the widest opportunity for student to learn in their own way and style (Aliyari et al., 2019; Kulakow \& Raufelder, 2020). The student center learning pattern will make students learn to access learning materials and check assignments independently, this will have a positive impact on progress and increase student achievement. The criteria for the success of the learning process are not measured by the extent to which students have mastered the subject matter, but are measured by the extent to which the achievement of learning objectives through the learning process has been carried out by students (Ramadania \& Aswadi, 2020; Sirait, 2021).

Based on these problems, it is known that fifth-grade students at SD N 4 Peliatan need learning media that can increase active participation in learning, so that the classroom atmosphere becomes livelier. Therefore, the development of learning media adopted from Monopoly games that are interesting and fun is carried out. The use of learning media with the concept of playing while learning can lead to an active role for students, besides the concept of playing while learning can also led to creative, responsible, tolerant, and confident attitudes in students (Tapingkae et al., 2020). Thus, the existence of game-based media will make students feel happy and not bored with monotonous learning style. The principle of playing while learning in monopoly media will bring students into learning activities that initially feel boring and become more fun. Several research finding that has been done previously show that monopoly media is generally suitable for use in learning. The thematic monopoly media developed by Iksal, (2020) was declared feasible and effective to be used in the integrated thematic learning process. Subsequent research that developed monopoly smart game (MSG) media by Yulianti \& Wulandari, (2019) resulted in monopoly media which was declared feasible and practical to use in learning in elementary school. In addition, the monopoly media developed for plant structure and tissue materials is classified as very good with feasibility indicators, which include appearance, efficiency is in very good qualification (Andriyani, 2020). The monopoly media produced in this study has a weakness, namely the absence of instructions that explain specifically about playing techniques or how to use monopoly media. Therefore, this can be led to differences in the perception of each student which results in the emergence of misunderstandings in students.

The monopoly learning media developed in this study was specifically for learning the sub-term of animal movement organs in fifth-grade elementary school. Monopoly learning media can provide a number of benefits for students, these benefits includes the following; monopoly can improve the process of students social interaction, hone students intelligence, help learn to manage strategies and playing skills, introduce the journey of life, improve students ability to solve a problem, teach students to learn to manage money wisely, and teach students about the purpose of life (Suhendrianto, 2017). The developed 
monopoly learning media is very necessary in the implementation of the integrated thematic learning process, because the monopoly learning media has integrated several lesson contents on the subtheme of animal movement organs. This monopoly learning media is expected to instill meaningful knowledge for each student. In addition, the monopoly learning media indirectly has an advantage that it can insert character education in each player through the procedures and rules of the game that are set. The characters education in question is obedience to the rules of the game, tolerance, and discipline. Character education will help a person to increase care, confidence, and act on the basis of aesthetic values (Antara, 2019; Komara, 2018).

This development research was conducted with the aim of producing a simple monopoly learning media on the subtheme of animal movement organs, to increase the active participation of elementary school students in integrated thematic learning. The increased active participation of students in the integrated thematic learning process will make the learning atmosphere more enjoyable. With the active participation of students in learning, it will facilitate the achievement of optimal learning objectives and the learning process become more meaningful. Meaningful learning is participatory learning for students, and the material presented to students can be accepted and understood optimally. The implications of empirical research can make students motivated to take part in learning so that the classroom atmosphere becomes livelier. In addition, with the existence of this monopoly learning media, teachers can avoid delivering the material directly to students. Monopoly media also trains students to learn to find out independently and foster an attitude of tolerance. Therefore, the role of teacher is not only having a source of learning but as a facilitator who facilitates the needs of students in following the learning process.

\section{METHOD}

This type of research and development (R\&D) research produces a product in the form of a simple monopoly learning media on the subtheme of animal movement organs. The existence of procedures in research is very important to know the steps that need to be followed and carried out so the product that you want to develop can be realized in accordance with expectations (Ardiyanto \& Fajaruddin, 2019). The model that is used as a reference procedure in the development of simple monopoly learning media on the sub-theme of animal movement's organs is the ADDIE model which consist of 5 steps. Dick \& Carry (1996) explains that the ADDIE model uses five steps of development (Kartika Sari, 2017). These steps are: (1) the first step is analysis, at this step a need analysis is carried out at SD N 4 Peliatan, (2) after conducting a needs analysis, a simple monopoly learning media design is carried out using Microsoft word software 2016 and paint applications, (3) further development is carried out by realizing media design into real products through the printing process with a printing press. The material used include luster paper, buffalo paper, dice and game pieces as components of media completeness. While the media packaging use pipes that are painted/colored according to the media theme, semi-leather straps are added to make it easier to carry the media. At this step, testing of the validity of the product by experts and practitioners is also carried out to determine the feasibility of the product when it used in learning. (4) The fourth step is the implementation, and (5) the last step is the evaluation. Due to time constraints and the conditions of the COVID-19 pandemic, the implementation and evaluation step cannot be carried out. The research subjects at the product validation steps in this development research include a material expert, an instructional design expert, and a practitioner (grade V teacher at SD N 4 Peliatan). The product trial design is presented in Figure 1.

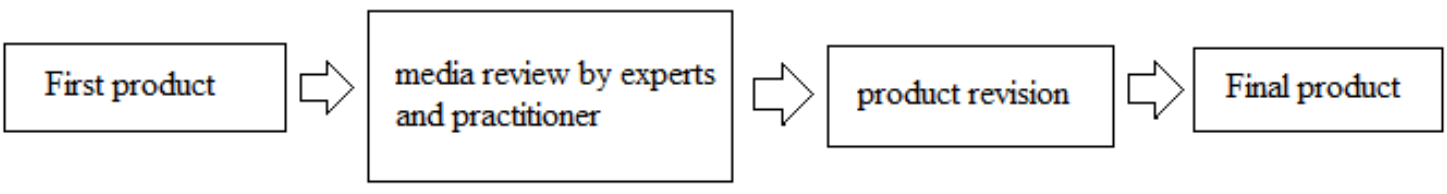

Figure 1. Trial Design Chart

Meanwhile, data collection in research can be done in certain ways, such as observations, literatures searches, questionnaires, and interviews (Ichsan \& Ali, 2020; Suliyanto, 2017). In this development research, data were collected by using the observation method at SD N 4 Peliatan. The questionnaire that used is a questionnaire containing statements and suggestions related to the developed media. The results of the questionnaire are needed to determine the validity of the developed media. The instrument that used in this study is a Likert scale questionnaire in the form of monopoly media assessment sheet. The monopoly media assessment sheet was given to the fifth-grade teacher at SD N 4 Peliatan and two lecturers as expert to assess the validity of the developed monopoly media. The 
instrument used must be valid before being tasted in the study. The Likert scale is one of the easiest scale to use (Budiaji, 2013). The Likert scale is also sated as a psychometric scale that is most often used in research in the form of surveys and is commonly used in the questionnaire (Maryuliana, 2016). Therefore, to fill out a questionnaire that uses a Likert scale, respondents fill out the level of agreement with the existing statements by choosing one of the available options. For quantitative analysis, the answer scale can be scored as follows; strongly agree (SS) get score of 5, agree (S) get a score of 4, undecided (RG) get a score of 3 , disagree (TS) get a score of 2, strongly disagree (STS) get a score of 1 . Instruments are presented in table 1 , table 2 , table 3 , and table 4 .

Table 1. Content Expert Instruments

\begin{tabular}{clll}
\hline No. & \multicolumn{1}{c}{ Indicator } & \multicolumn{1}{c}{ Item Number } \\
\hline 1. & Material Feasibility & $1,2,3,4,5,6,7,8$ & \\
2. & Language Assessment & $9,10,11,12$ & \\
\hline
\end{tabular}

Table 2. Learning Media Expert Instruments

\begin{tabular}{clll}
\hline No. & \multicolumn{1}{c}{ Indicator } & \multicolumn{1}{c}{ Item Number } \\
\hline 1. & Media Display & $1,2,3,4,5,6$ & \\
2. & Attactiveness & $8,9,10,11,12,13$ & \\
3. & Language Use & 14,15 & \\
\hline
\end{tabular}

Table 3. Learning Design Expert Intruments

\begin{tabular}{clll}
\hline No. & \multicolumn{1}{c}{ Indicator } & Item Number \\
\hline 1. & Learning Objectives & 1,2 & \\
2. & Learning Method & 3 & \\
3. & Learning Media & $4,5,6,7,8,9,10$ & \\
\hline
\end{tabular}

Table 4. Practitioner Expert Instruments

\begin{tabular}{cll}
\hline No. & \multicolumn{1}{c}{ Indicator } & \multicolumn{1}{c}{ Item Number } \\
\hline 1. & Material suitabilty & $1,2,3$ \\
2. & Language Use & $4,5,6,7$ \\
3. & Media Display & $8,9,10,11,12,13,14,15$ \\
4. & Evaluation & 16 \\
\hline
\end{tabular}

The feasibility of an instrument is determined from the results of the content validity test by two experts (judges). To determine the coefficient of content validity, the result of the assessment of the two experts on the monopoly instruments were entered into $2 \times 2$ cross tabulation consisting of columns A, B, $C$, and D. The result of the assessments of content validity using the Gregory formula. After getting the results of content validity using the Gregory formula, the next step is to determine the category of content validity coefficient (Dedi Kusnadi, 2020; Widiartini, 2017). The assessment instrument used in this study has been tested and analyzed using the Gregory formula, the instrument used in this study as a whole is in the category of very good content validity so that the instrument has been validly submitted to experts and practitioners to assess monopoly learning media.

Data analysis techniques that used in this development research are descriptive qualitative statistical analysis techniques and quantitative descriptive statistical analysis. Qualitative descriptive statistical analysis method was used to process data in the form of criticism, suggestions, and input from reviews by experts and practitioners on monopoly media developed through the of questionnaires. The result of the analysis is used to make improvements and development monopoly media. While the quantitative descriptive statistical analysis method is used to describes the averages score of monopoly media developed in the form of a descriptive percentage presentase (Tegeh \& Jampel, (2017:222). The next, the averages score obtained is then converted using five-scale conversion guideline to fine out the validity of the developed media. The five-scale conversion guidelines ussed can be seen in table 5 . 
Table 5. Achievement Rate Conversions on a five scale

\begin{tabular}{cc}
\hline Achievement Level (\%) & Qualifications \\
\hline $\mathbf{9 0 - 1 0 0}$ & Very Good \\
$\mathbf{7 6 - 8 9}$ & Good \\
$\mathbf{6 5 - 7 5}$ & Enaugh \\
$\mathbf{5 5 - 6 4}$ & Less \\
$1-54$ & Bad \\
\hline
\end{tabular}

\section{RESULT AND DISCUSSION}

\section{Result}

This study is developed products in the form of simple monopoly learning media on the subtheme of animal movement organs on grade $\mathrm{V}$ elementary school. Product development is done with the ADDIE development model. In the first step, the analysis phase shows that the learning achievement students of grade V at SD N 4 Peliatan in the learning of animal movement organs is not optimal. This is because the learning media that available at the school is very limited. The availability media only in the form of images media, therefore the students are not interested and lack of enthusiastic in participating in learning, the impact of students becomes less active in integrated thematic learning. Therefore, the learning media is needed to be able to motivate and increase the active participation of students in learning process. Furthermore, at the design step card and board game designs are produced on the monopoly learning media made by Microsoft word 2016 and the paint application as show in figure 1 and 2. After going through the design step and obtaining a monopoly media component design, proceed to the development steps. At the development step, the design is implemented into a tangible product form through the printing process. The design that has been realized into real product at the development step are shows in the figure 3 and 4 . Furthermore, after the monopoly learning media is printed, it is continued with product testing activities to experts and practitioners. Product trials were conducted to determine the validity or feasibility of monopoly learning media before it is used in the school. The results of product trials based on assessments by subject matter experts, learning designs experts, and practitioners are presented in table 6.

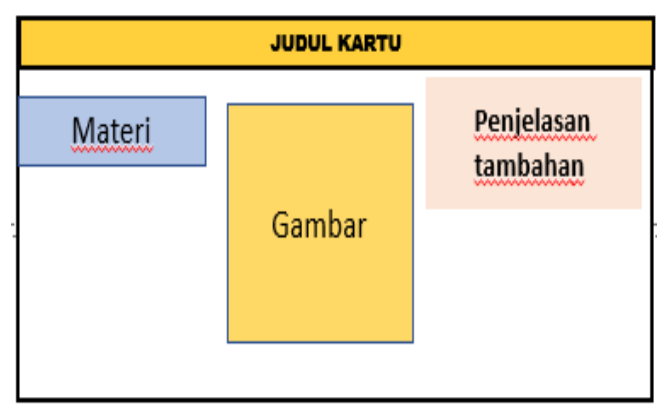

Figure 1. Cards Design on Monopoly Media

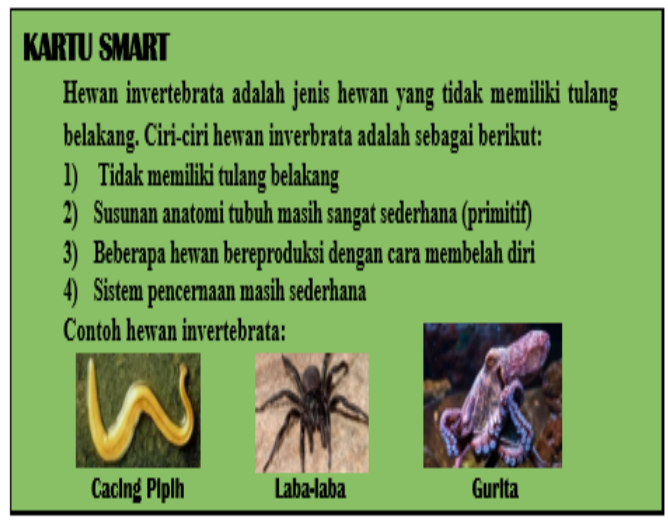

Figure 3. Smart Cards

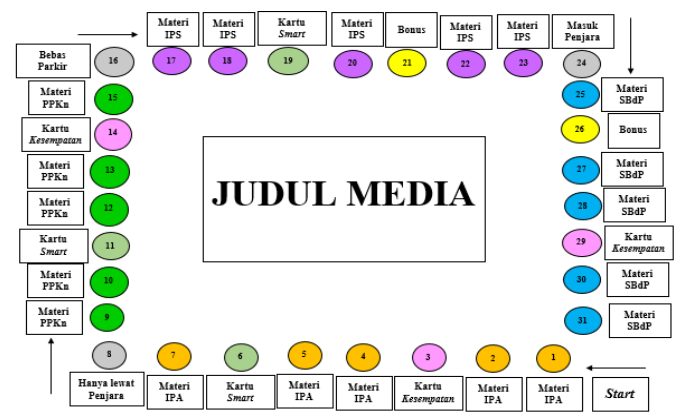

Figure 2. Board Game Design

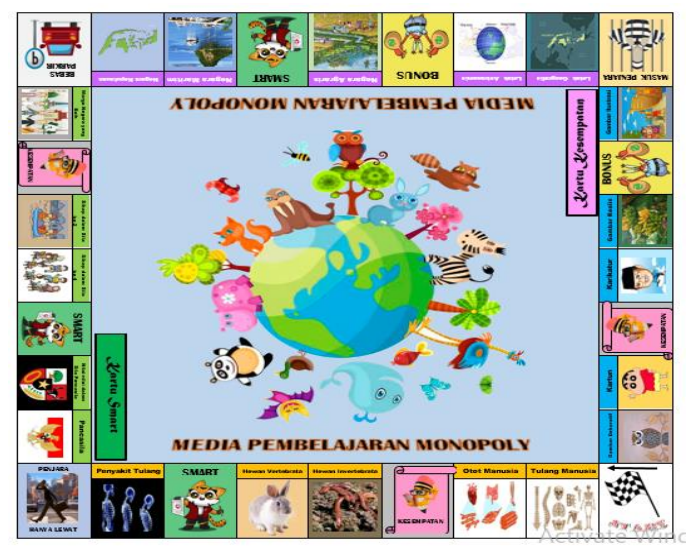

Figur 4. Bord Monopoly Game 
Table 6. Product Validity Test Result

\begin{tabular}{|c|c|c|c|}
\hline No & Trial Subject & Validity Result & Description \\
\hline 1. & Material Expert Test & $95 \%$ & Very Good \\
\hline 2. & Learning Media Expert Test & $96 \%$ & Very Good \\
\hline 3 & Learning Design Expert Test & $94 \%$ & Very Good \\
\hline \multicolumn{2}{|c|}{ Average } & 95\% & Very Good \\
\hline No. & Trial Subject & Validity Result & Description \\
\hline 1. & Practitioner & $92,5 \%$ & Very Good \\
\hline Ave & age & $92,5 \%$ & Very Good \\
\hline
\end{tabular}

As a subject test, experts and practitioners provide suggestions and comments on the developed monopoly learning media. The advice given is used as a reference for making the improvements to the monopoly learning media so that the media becomes better and more interesting. In addition, going through the revision steps based on the suggestions that given can make monopoly media more valuable in term of aesthetics. Learning media is said to have aesthetic value if the media composes that the layout of images and writing well and symmetrically, adjust the size of each media component, selects the interesting images or animations, and uses clear symbolism (Gustina \& Rahmayuni, 2016; Said et al., 2017). The selection of the right colors in the media components and according to the characteristics of students is also a supporting factor for aesthetically valuable learning media.

\section{Discussion}

This research has produced a product in the form of simple monopoly learning media on the subtheme of animal movement organs for fifth grade students at SD N 4 Peliatan. Overall, the monopoly learning media was declared valid with very good qualifications by the experts through the validity test. Meanwhile, based on the response of practitioners, monopoly media is said to be very good for use in the learning process. The acquisition of qualifications is very good because the monopoly learning media was developed with a systematic and clear ADDIE development model, so that the monopoly media have a certain quality and very attractive for physical or motor activities for elementary school students. Through the analysis stage, it is known that the fifth-grade students of SD N 4 Peliatan have relatively low learning outcomes in integrated thematic learning sub-theme of the animal movement organs. The low learning outcomes are due to the lack of availability of learning media in schools. While the existence of adequate media is very important in teaching (Silverman et al., 2019). The available media is only limited to visual media in the form of images which causes students not to be interested in participating in learning. This causes the learning atmosphere to be passive and unpleasant (Rollins et al., 2018). Therefore, an interesting and fun learning media was developed as an intermediary to convey material to students. Learning media can be said to be good if the media developed is in accordance with the subject matter, effective, interesting, and in accordance with the learning objectives (Dostál, 2015; Fortunati \& O'Sullivan, 2019). The integrated thematic learning process can be successful if the learning media is in accordance with the chosen or used learning strategy (Hui et al., 2021). The selection of learning strategies that are suitable for students' conditions will have an impact on the optimal acquisition of student learning outcomes (Marcineková et al., 2020).

Regarding to the design steps in the ADDIE model a monopoly learning media design for the subtheme of animal movement organs was made. The design was made with the help of Microsoft word 2016 and the paint application. Designing begins with determining the shape and size of the media. This is done with the aim of increasing the efficiency and attractiveness of the media. The shape and size of the media must pay attention to the characteristics of students, so that their use is in accordance with the expected goals. The design and selection of images is also adjusted to the level of development of elementary school-ages children, therefore that the media can attract interest and raise students' learning motivation which will affect the achievement of learning outcomes (Sidarta \& Yunianta, 2019). Making media design still has to pay attention to the learning objectives to be achieved. The learning objectives that have been formulated are in accordance with the ABCD formula (audience, behavior, condition, degree). Therefore that in the integrated thematic learning process, the learning method emphasizes the application of the concept of learning while doing something, because it will affect the meaningfulness of learning for students (Varun dan Kalpana, 2016). Therefore, the urgency of the position of the media in the learning process is very important, even almost parallel with the learning method (Mustika, 2015). After obtaining the design of monopoly learning media, then the design is realized into a real product at the development step. 
At the development step, the monopoly learning media design is realized into real media through the printing process. The board game on monopoly learning media is printed with high quality luster paper material measuring $50 \mathrm{~cm} \times 50 \mathrm{~cm}$. Meanwhile, the cards on monopoly media were printed with buffalo paper which was then laminated. For procurement of other components consisting of dice, game pieces, and play money, they were obtained randomly from various sources. After going through the process of realizing the media, then the monopoly media is assessed for validity or feasibility trials to experts and practitioners (grade V teacher at SD N 4 Peliatan). Based on the results of the assessment by material experts, learning media experts, learning design experts, and practitioners, monopoly media is considered valid with very good qualifications therefore that it is suitable for use in integrated thematic learning in fifth-grade elementary school. Monopoly learning media is considered to have fulfilled the concept of learning while doing something that can increase students' motivation and participation in the learning process. Many factors influence the assessment of the feasibility of a developed learning media. These factors include design attractiveness, product resilience, development strategy, and realm needs (Wang et al., 2017). This simple monopoly learning media packs very complex material from several integrated lesson content to be more interesting and simpler. In a learning system, media is one of the important components in it to help teachers convey complex material into simpler ones to students (Tafonao, 2018). The function of the media in the learning process is as a component that contains learning messages that will be conveyed to students (Georgiou \& Kyza, 2021). Learning media is not an instructional system, but a means to deliver material to increase the effectiveness of learning (Cikarge \& Utami, 2018). Therefore, the media is said to be able to convey material to students if the media is in accordance with the level of development and mindset of students (Dewi, 2017; Eka Sari, 2016). In addition, the selection of media in learning must be adjusted to the needs, situations, and conditions of students.

The material presented in the simple monopoly learning media sub-theme of animal movement organs developed will be clearly understood by students if students can be directly involved in the learning process. The meaningful learning is learning that provides opportunities for students to learn the material directly and can relate it to authentic events (Ansori, 2020; Setyowati \& Fimansyah, 2018). The meaningful learning cannot be separated from the effective use of language in learning. The effectiveness of language affects the success of message transformation between the senders of the message to the recipient of the message (Wisman, 2017). The suitability of the use of language in learning media with the learning process is one of the success factors of the media in conveying material to students (Jayadianti et al., 2015). The use of language greatly affects the course of communication between the communicator and the communicant, therefore the embedding of language in the media must be clear and not have multiple meanings so that there are no differences in interpretation (Feng et al., 2020). Thus language has an important role in the presentation of material, therefore that the learning process can run smoothly and optimally if it is supported by effective and efficient language in the learning media used. Learning media can help students to be active in learning if the media can be used directly by students. This will create a pleasant learning atmosphere for students. A pleasant learning atmosphere will make students motivated and feel meaningful learning.

In addition, the developed monopoly media has advantages in terms of the relevance of the questions to the subject matter. Therefore, the overall presentation of the material on simple monopoly learning media is very good. The implementation of integrated learning in the 2013 curriculum requires students to learn independently (Nurita, Nurhaidah M. Insya Musa, 2018). The use of media in the implementation of the learning process is an important need that cannot be ignored, because the media can help teachers convey material content in accordance with learning principles effectively to students (Muslem \& Abbas, 2017). Therefore, meaningful learning is learning that can be done independently by students, one of which is through the use of fun learning media in the learning process. Edgar Dale made a classification according to the level from the most concrete to the most abstract (Zhang et al., 2019). Thus, the selection of media must be adjusted to the level of development of elementary school ages children so that the subject matter can be delivered optimally. Monopoly simple learning media has the characteristic of being a print media that can increase students' focus and motivation in learning. Due to time constraints and conditions, it is still in the COVID-19 pandemic, therefore the implementation and evaluation steps cannot be carried out.

\section{CONCLUSION}

This development research resulted in a simple monopoly learning media product on the subtheme of animal movement organs which was developed using the ADDIE model. Based on the results of reviews by experts, the simple monopoly learning media is declared valid with very good qualifications 
so that it is suitable for use in integrated thematic learning. In addition, monopoly media was also declared very well qualified according to the teacher's response based on the results of a review by a practitioner. Thus, it can be said that simple monopoly learning media is suitable for use in integrated thematic learning, especially on the sub-theme of animal movement organs in grade $\mathrm{V}$ of elementary school. Monopoly media is considered able to increase students' active participation in the learning process, therefore students can receive learning more meaningfully and the learning atmosphere in the classroom becomes more enjoyable.

\section{REFERENCES}

Aliyari, shahla, Pishgooie, A. H., Abdi, A., Mazhari, M. S., \& Nazari, M. R. (2019). Comparing two teaching methods based on concept map and lecture on the level of learning in basic life support. Nurse Education in Practice, 38(May), 40-44. https://doi.org/10.1016/j.nepr.2019.05.008.

Andriyani, F., Saraswati, R. R., Melasari, D., Putri, A., \& Sumardani, D. (2020). Kelayakan Media Pembelajaran Monopoli pada Materi Struktur dan Fungsi Jaringan Tumbuhan. Risenologi : Jurnal Sains, Teknologi, Sosial, Pendidikan, Dan Bahasa, 5(1), 20-25. https://doi.org/10.47028/j.risenologi.2020.51.60.

Ansori, Y. Z. (2020). Pembinaan Karakter Siswa Melalui Pembelajaran Terpadu Di Sekolah Dasar. Jurnal Educatio FKIP UNMA, 6(1), 177-186. https://ejournal.unma.ac.id/index.php/educatio/article/download/308/202/.

Antara, P. A. (2019). The Implementation Of Early Childhood Character Education. Jurnal Ilmiah VISI PGTK PAUD Dan Dikmas, 14(1), 17-26.

Ardiyanto, H., \& Fajaruddin, S. (2019). Tinjauan atas artikel penelitian dan pengembangan pendidikan di Jurnal Keolahragaan. Jurnal Keolahragaan, 7(1), 83-93. https://doi.org/10.21831/jk.v7i1.26394.

Brown, C., \& Flood, J. (2020). The three roles of school leaders in maximizing the impact of Professional Learning Networks: A case study from England. International Journal of Educational Research, 99(November 2019), 101516. https://doi.org/10.1016/j.ijer.2019.101516.

Budiaji, W. (2013). Skala Pengukuran dan Jumlah Respon Skala Likert. Jurnal Ilmu Pertanian Dan Perikanan, 2(2), 127-133.

Cikarge, G. P., \& Utami, P. (2018). Analisis Dan Desain Media Pembelajaran Praktik Teknik Digital Sesuai Rps. Elinvo (Electronics, Informatics, and Vocational Education), 3(1), 92-105. https://doi.org/10.21831/elinvo.v3i1.20509.

Dedi Kusnadi, A. wild. indra nanna. (2020). Jurnal MATEMATICS PAEDAGOGIC. Jurnal Matematics Paedagogic, IV(2), 163-174.

Dewi, K. (2017). Pentingnya Media Pembelajaran. Jurnal Pendidikan Anak Usia Dini, 1 No.1, 81-96.

Dostál, J. (2015). Activating Devices and Their Use in e-Learning - Focussed on Handicapped Students. Procedia Social and Behavioral Sciences, 176, 284-290. https://doi.org/10.1016/j.sbspro.2015.01.473.

Eka Sari, Luh Putu, Ardana, I Ketut, Ngr Semara Putra, D. (2016). Penerapan Metode Bercerita Berbantuan Media Gambar Berseri Untuk Meningkatkan Kemampuan Berbicara Pada Anak Kelompok A1. E-Journal Pendidikan Anak Usia Dini Universitas Pendidikan Ganesha, 4(1).

Fakhrurrazi, F. (2018). Hakikat Pembelajaran Yang Efektif. At-Tafkir, 11(1), 85. https://doi.org/10.32505/at.v11i1.529.

Feng, C., Rao, Y., Nazir, A., Wu, L., \& He, L. (2020). Pre-trained Language Embedding-based Contextual Summary and Multi-scale Transmission Network for Aspect Extraction. Procedia Computer Science, 174(2019), 40-49. https://doi.org/10.1016/j.procs.2020.06.054

Fortunati, L., \& O'Sullivan, J. (2019). Situating the social sustainability of print media in a world of digital alternatives. Telematics and Informatics, 37(March), 137-145. https://doi.org/10.1016/j.tele.2018.04.005.

Georgiou, Y., \& Kyza, E. A. (2021). Bridging narrative and locality in mobile-based augmented reality educational activities: Effects of semantic coupling on students' immersion and learning gains. International Journal of Human Computer Studies, 145, 102546. https://doi.org/10.1016/j.ijhcs.2020.102546.

Gustina, S., \& Rahmayuni, I. (2016). Pengembangan Potensi Estetik Dalam Pembelajaran Matematika Sekolah Dasar. Jurnal Pelangi, 8(2), 191-202.

Hui, L., de Bruin, A. B. H., Donkers, J., \& van Merriënboer, J. J. G. (2021). Stimulating the intention to change learning strategies: The role of narratives. International Journal of Educational Research, 107(January). https://doi.org/10.1016/j.ijer.2021.101753.

Ichsan, I., \& Ali, A. (2020). Metode Pengumpulan Data Penelitian Musik Berbasis Observasi Auditif. Musikolastika: Jurnal Pertunjukan Dan Pendidikan Musik, 2(2), 85-93. https://doi.org/10.24036/musikolastika.v2i2.48.

Iksal, M. (2020). engembangan Media Monopoli Tematik Pada Tema Daerah Tempat Tinggalku Untuk Siswa Kelas IV di Madrasah Ibtidaiyah Rahmatullah Kota Jambi. 21(1), 1-9.

Ilham Raharjo, D. (2015). Pengaruh Strategi Pembelajaran (Tematik Versus Konvensional) dan Gaya Kognitif terhadap Prestasi Belajar Siswa Kelas III Sekolah Dasar. Jurnal Pendidikan Humaniora, 3(2), 85-90.

Jayadianti, H., Nugroho, L. E., Sanntosa, P. I., Widayat, W., \& Pinto, C. S. (2015). Ontology Sebagai Solusi Pencarian Makna Ambigu Dalam Dalam Sistem Yang Heterogen. Telematika, 10(1). https://doi.org/10.31315/telematika.v10i1.386.

Kartika Sari, B. (2017). Desain pembelajaran model addie dan implementasinya dengan teknik jigsaw. 87-102.

Komara, E. (2018). Penguatan Pendidikan Karakter dan Pembelajaran Abad 21. SIPATAHOENAN: South-East Asian Journal for Youth, Sports \& Health Education, 4(1), 17-26. 
Kulakow, S., \& Raufelder, D. (2020). Enjoyment benefits adolescents' self-determined motivation in student-centered learning. International Journal of Educational Research, 103(April), 101635. https://doi.org/10.1016/j.ijer.2020.101635.

Lin, P.-Y., Chai, C.-S., Jong, M. S.-Y., Dai, Y., Guo, Y., \& Qin, J. (2021). Modeling the structural relationship among primary students' motivation to learn artificial intelligence. Computers and Education: Artificial Intelligence, 2(October 2020), 100006. https://doi.org/10.1016/j.caeai.2020.100006.

Marcineková, T., Borbélyová, D., \& Tirpáková, A. (2020). Optimization of children's transition from preschool and family environment to the first grade of primary school in Slovakia by implementation of an adaptation programme. Children and Youth Services Review, 119(June), 105483. https://doi.org/10.1016/j.childyouth.2020.105483.

Maryuliana, M., Subroto, I. M. I., \& Haviana, S. F. C. (2016). Sistem informasi angket pengukuran skala kebutuhan materi pembelajaran tambahan sebagai pendukung pengambilan keputusan di sekolah menengah atas menggunakan skala likert. TRANSISTOR Elektro Dan Informatika, 1(1), 1-12.

Muslem, A., \& Abbas, M. (2017). The effectiveness of immersive multimedia learning with peer support on english speaking and reading aloud. International Journal of Instruction, 10(1), 203-218. https://doi.org/10.12973/iji.2017.10113a.

Mustika, Z. (2015). Urgenitas Media Dalam Mendukung Proses Pembelajaran Yang Kondusif. CIRCUIT: Jurnal Ilmiah Pendidikan Teknik Elektro, 1(1), 60-73. https://doi.org/10.22373/crc.v1i1.311.

Ng, P. T. (2015). What is quality education? How can it be achieved? The perspectives of school middle leaders in Singapore. https://doi.org/10.1007/s11092-015-9223-8.

Nugroho, B. H. (2019). Efek pembelajaran kooperatif dalam proses pembelajaran dan pencapaian tujuan pembelajaran pada mata kuliah pharmaceutical engineering. Refleksi Pembelajaran Inovatif, 1(2), 136-146. https://doi.org/10.20885/rpi.vol1.iss2.art4.

Nurita, Nurhaidah M. Insya Musa, M. Y. (2018). Kendala-kendala Guru dalam Mengimplementasikan Kurikulum 2013 di SD Negeri 7 Teupah Barat. Gastrointestinal Endoscopy, 10(1), 279-288.

Raggl, A. (2015). Teaching and learning in small rural primary schools in Austria and Switzerland-Opportunities and challenges from teachers' and students' perspectives. International Journal of Educational Research, 74, 127135. https://doi.org/10.1016/j.ijer.2015.09.007.

Ramadania, F., \& Aswadi, D. (2020). Blended Learning dalam Merdeka Belajar Teks Eksposisi. STILISTIKA: Jurnal Bahasa, Sastra, Dan Pengajarannya, 5(1), 10-21. https://doi.org/10.33654/sti.v5i1.1014.

Rollins, L., Gibbons, J. A., \& Cloude, E. B. (2018). Affective change greater for unpleasant than pleasant events in autobiographical memory of children and adults: A retrospective study. Cognitive Development, 47(March 2017), 46-52. https://doi.org/10.1016/j.cogdev.2018.03.002.

Said, A. A., Cahyadi, D., \& Arifin, I. (2017). Struktur Media Pembelajaran dalam Perspektif Desain Komunikasi Visual. Tanra, 4(2), 1-13.

Setyowati, R., \& Fimansyah, W. (2018). Upaya Peningkatan Citra Pembelajaran IPS Bermakna di Indonesia. Jurnal PIPSI (Jurnal Pendidikan IPS Indonesia), 3(1), 14. https://doi.org/10.26737/jpipsi.v3i1.544.

Sidarta, K. T., \& Yunianta, T. N. H. (2019). Pengembangan Kartu Domano (Domino Matematika Trigono) Sebagai Media Pembelajaran Pada Matakuliah Trigonometri. Scholaria: Jurnal Pendidikan Dan Kebudayaan, 9(1), 62-75. https://doi.org/10.24246/j.js.2019.v9.i1.p62-75.

Silverman, R. D., Artzi, L., McNeish, D. M., Hartranft, A. M., Martin-Beltran, M., \& Peercy, M. (2019). The relationship between media type and vocabulary learning in a cross age peer-learning program for linguistically diverse elementary school students. Contemporary Educational Psychology, 56, 106-116. https://doi.org/10.1016/j.cedpsych.2018.12.004.

Sirait, J. E. (2021). Analisis Pengaruh Kompetensi Guru Terhadap Keberhasilan Pembelajaran Di Sekolah Dasar Bethel Tanjung Priok Jakarta Utara. DIEGESIS: Jurnal Teologi Sekolah Tinggi Teologi Bethel Indonesia, 6(1), 49-69. https://doi.org/https://doi.org/10.46933/DGS.vol6i149-69.

Skuballa, I. T., Dammert, A., \& Renkl, A. (2018). Two kinds of meaningful multimedia learning: Is cognitive activity alone as good as combined behavioral and cognitive activity? Learning and Instruction, 54(July 2017), 35-46. https://doi.org/10.1016/j.learninstruc.2018.02.001.

Suhendrianto. (2017). Pengembangan Media Pembelajaran Monopoli Tematik untuk Meningkatkan Motivasi Belajar Siswa Kelas IV MIN Tegalasri Kec. Wlingi Kab. Blitar. Universitas Islam Negeri Malang Maulana Malik Ibrahim Malang.

Suliyanto. (2017). Pelatihan Metode Pelatihan Kuantitatif. Journal of Chemical Information and Modeling, 5(2), 223232.

Tafonao, T. (2018). Peranan Media Pembelajaran Dalam Meningkatkan Minat Belajar Mahasiswa. Jurnal Komunikasi Pendidikan, 2(2), 103. https://doi.org/10.32585/jkp.v2i2.113

Tapingkae, P., Panjaburee, P., Hwang, G. J., \& Srisawasdi, N. (2020). Effects of a formative assessment-based contextual gaming approach on students' digital citizenship behaviours, learning motivations, and perceptions. Computers and Education, 159(August 2019), 103998. https://doi.org/10.1016/j.compedu.2020.103998.

Tegeh, I. M. dan J. N. (2017). Metode Penelitian Pengembangan. Universitas Pendidikan Ganesha.

Varun and Kalpana Vebugopal. (2016). Impact of Thematic Approach on Communication skills in Preschoo. 2.

Wang, X., Wang, Z., Huang, Y., Liu, Y., Zhang, J., Heng, X., \& Zhu, D. (2017). Identifying R\&D partners through SubjectAction-Object semantic analysis in a problem \& solution pattern. Technology Analysis and Strategic Management, 29(10), 1167-1180. https://doi.org/10.1080/09537325.2016.1277202.

Widiartini, N. K. (2017). Uji validitas instrumen pengukuran kualitas modifikasi motif dan bahan pada kain tenun 
mastuli. 530-535.

Wisman, Y. (2017). Komunikasi Efektif Dalam Dunia Pendidikan. Jurnal Nomosleca, 3(2), 646-654. https://doi.org/10.26905/nomosleca.v3i2.2039.

Yulianti, WUlandari, D. A. (2019). Pengembangan Media Monopoly Smart Games (Msg) Dalam Pembelajaran Tematik Kelas Iv Sd. Pengaruh Model Bermain Peran Berbantuan Atribut Terhadap Hasil Belajar IPS Melalui Karakter Gotong Royong, 3(November), 149-157.

Zhang, Q., Li, M., Wang, X., \& Ofori, E. (2019). Dr. Edgar Dale. TechTrends, 63(3), $240-242$. https://doi.org/10.1007/s11528-019-00395-1. 